\title{
Influence of Pulsed Electromagnetic Field on Plant Growth, Nutrient Absorption and Yield of Durum Wheat
}

\author{
Nikolaos KATSENIOS ${ }^{1 *}$, Victor KAVVADIAS ${ }^{1}$, Sideris THEOCHAROPOULOS ${ }^{1}$, \\ Dimitrios BILALIS ${ }^{2}$, Zaharias IOANNOU ${ }^{1}$, Antonios PAPADOPOULOS ${ }^{1}$, \\ Nektaria LIAKOPOULOU ${ }^{1}$
}

\author{
${ }^{1}$ Hellenic Agricultural Organization-Demeter, Institute of Soil and Water Resources,DepartmentofSoil Science of Athens, Lycourissi,Greece; nkatsenios@gmail.gr \\ ("correspondingauthor);vkavvadias.kal@nagref.gr; sid_theo@otenet.gr; zioan@teemail.gr; a.papadopoulo@@bpi.gr;nekliak@yahoo.gr \\ 2.Agricultural University of Athens, Laboratory of Agronomy, Iera Odos 75, Athens, Greece; bilalisdimitrios@yahoo.gr
}

\begin{abstract}
Researchers have adopted the use of magnetic field as a new pre-sowing, environmental friendly technique. Enhancements on plant characteristics with economic impact on producer's income could be the future of a modern, organic and sustainable agriculture. A field experiment was established at Soil Science Institute of Athens, Lycovrissi, Greece, in the winter of 2014. Two durum wheat cultivars were used. It was a pot experiment with 6 treatments ( 2 cultivars with 3 magnetic field time exposure). The seeds were treated using a PAPIMI electromagnetic field generator for 0,30 and 45 minutes one day before planting. The experiment followed a completely randomized design with six treatments and 30 replications. The aim of this study was to evaluate the positive effect of magnetic field pre-sowing treatment in a wide range of plant measurements, including yield. The influence of pulsed electromagnetic field on two varieties of durum wheat seeds showed some statistically significant differences at the 0.05 level in growth measurements, physiological measurements and root growth measurements. Plant tissue analysis showed that magnetic field treatments had higher values than control in total nitrogen, phosphorus, potassium, magnesium, copper (only MF-45), zinc (only MF-30) and boron content, although values showed statistically significant differences only in total nitrogen. The results indicate that this innovative technique can increase the yield of durum wheat, through enhanced absorption of nutrients. Pre-sowing treatment of the seeds leads to vigorous plant growth that are more productive.
\end{abstract}

Keywords: durum wheat, growth, magnetic field, soil analysis, tissue analysis

\section{Introduction}

The incorporation of an innovative, environmental friendly technique in agricultural practice that is capable to enhance plant growth and increase yield is a desirable evolution for sustainable agriculture. Researchers have adopted the use of magnetic field as a new pre-sowing, environmental friendly technique. Enhancements on plant characteristics with economic impact on producer's income could be the future of a modern and organic agriculture. The growing needs in organic agriculture of new methods to replace chemical emergency promoters lead to the development of techniques such as magnetic fields (Bilalis et al., 2012b).

Although mankind knows the existence of the Earth's magnetic field since ancient times and despite the fact that it has always been one of the key features of the environment, until recently the study of the effect of the magnetic field in agronomic science was absent. Each region is characterized by a number of abiotic factors (water, air, soil, temperature) including the magnetic field. However, for many years, the magnetic field of the Earth constituted as an invariable parameter of the environment that has not been taken into account in plant studies (Katsenios, 2013).

In the last decades, studies on the influence of magnetic fields on plants have multiplied and the knowledge that is produced from these researches has accumulated to provide clearer information about the effects of magnetic field on plants. The results have shown that different types of magnetic fields, at different levels of field strength and duration exposure have specific, either positive or negative, effects. The majority of the researchers use the magnetic field as a pre-sowing technique, as an inexpensive, environmentally friendly technique, which can be applied with relative ease (Vashisth and Nagarajan, 2010).

Magnetic fields have been reported to improve growth and development of tomato (De Souza et al., 2006), seed germination and early growth characteristics in sunflower (Vashisth and Nagarajan, 2010) and primary root growth of corn seedlings grown under 
506

constant influence of an alternating magnetic field (Muraji et al., 1998).

The influence of magnetic field on chemical elements has not been investigated thoroughly. In early stages of cotton, it was found that electromagnetic field promoted chemical elements accumulation (Bilalis et al., 2013). More specific, chemical analysis showed that magnetic field has improved elements percentage. Nitrogen, phosphorus, potassium, calcium and magnesium were higher in MF treatments. Strawberry plants that were treated with magnetic field strengths of $0.096,0.192$ and 0.384 Tesla $(T)$ in heated greenhouse conditions, showed that increasing MF strength from control to $0.384 \mathrm{~T}$ increased the $\mathrm{N}, \mathrm{K}, \mathrm{Ca}, \mathrm{Mg}, \mathrm{Cu}, \mathrm{Fe}, \mathrm{Mn}, \mathrm{Na}$ and $\mathrm{Zn}$ contents, but reduced $\mathrm{P}$ and $\mathrm{S}$ content (Esitken and Turan, 2004).

Pulsed electromagnetic field is widely investigated. Pulsed electromagnetic fields showed that it could replace hormones in vegetative propagation of oregano, stimulating rooting process in stem cuttings (Bilalis et al., 2012a). Furthermore, pulsed electromagnetic fields have been found to promote germination and improve early growth characteristics of cotton seedlings (Bilalis et al., 2012b). Recently, cherry tomato seeds were exposed to pulsed magnetic field (PMF) dose in the cycles of 2, 3, 5 or $6 \mathrm{~min}$ on and off where PMF dose of $3 \mathrm{~min}$ on and off cycle showed substantial enhancement of $23 \%$ in seedling vigor compared to other treatments (Gupta et al., 2015). Yield increased by $27 \%$ in plants from PMF primed seeds.

The aim of the current study was to evaluate the positive effect of magnetic field pre-sowing treatment in a wide range of plant measurements, from the early stages of growth till yield. Moreover, the study objective was to indicate that this innovative technique could increase the yield of durum wheat, through enhanced absorption of nutrients. The positive effect of magnetic field using simple pre-sowing treatment in characteristics with economic impact on producer's income, such as yield, could be the future of a modern, organic and sustainable agriculture.

\section{Materials and Methods}

The field experiment was established at Soil Science Institute of Athens, Lycovrissi, Greece, in the winter of 2014. Two durum wheat cultivars ('Thraki' and 'Mexicali 81', by Hellenic Agricultural OrganizationDemeter) were used.

It was a pot experiment with 6 treatments $(2$ cultivars with 3 magnetic field time exposure). The seeds were treated using a PAPIMI electromagnetic field generator for 0,30 and 45 minutes one day before planting. Nontreated seeds were used as control.

The PAPIMI device is a pulsed electromagnetic field (PEMF) generator (PAPIMI model 600; Pulse Dynamics, Athens, Greece). Manufacturer characteristics are: $35-80 \mathrm{~J} /$ pulse energy, $1 \times 10-6 \mathrm{~s}$ wave duration, 35 $80 \times 106 \mathrm{~W}$ wave power, amplitude of the order of 12.5 $\mathrm{mT}$, rise time $0.1 \mathrm{~ms}$, fall time $10 \mathrm{~ms}$, repetitive frequency of $3 \mathrm{~Hz}$.$) . The same device has been used in medical and$ agricultural studies (Milgram et al., 2004; Athanasiou et al., 2007; Bilalis et al., 2012b; Katsenios, 2013).
The experiment was carried out in a completely randomized design, with six treatments (Mex-0, Mex-30, Mex-45, Th-0, Th-30 and Th-45) and 30 replications. The quantity of seeds used was $16 \mathrm{~g} / \mathrm{m}^{2}$ for all cultivars.

Leaf area $\left(\mathrm{cm}^{2}\right.$ per plant) and stem dry weight (g per plant) were destructive measurements and took place at the 105 DAS (Days After Sowing). Leaf area was measured by using an automatic leaf area meter (Delta-T Devices Ltd, Burrwell, Cambridge, UK). Stem dry weight was measured by a precision balance after the samples were oven-dried at $70^{\circ} \mathrm{C}$ for three days, in order to measure the weight in grams per plant.

Before measuring root characteristics, each root sample was separated from the soil by washing the samples over a $5 \mathrm{~mm}$ mesh sieve, as regard to pot experiment. A formalin/acetic acid/alcohol (FAA) staining solution was used. The determination of root length and root surface was made by a high-resolution scanner, using DT software (Delta-T Scan version 2.04; Delta-T Devices Ltd, Burrwell, Cambridge, UK) (Kokko et al., 1993).

Measurements of photosynthetic rate $\left(\mu \mathrm{mol} \mathrm{CO} \mathrm{Cm}^{-2}\right.$ $\left.\mathrm{s}^{-1}\right)$ and transpiration rate $\left(\mathrm{mmol} \mathrm{H}_{2} \mathrm{O} \mathrm{m} \mathrm{m}^{-2} \mathrm{~s}^{-1}\right)$ were undertaken between the hours of 10:30 and 14:30 on fully expanded leaves, with five measurements per treatment. Measurements were made using an LCi Leaf Chamber Analysis System (ADC, Bioscientific, Hoddesdon, UK). Physiological measurements were taken at 105 DAS.

For the durum wheat tissue analysis, samples were oven-dried at $70{ }^{\circ} \mathrm{C}$ for 24 hours and then ashed in a furnace at $450{ }^{\circ} \mathrm{C}$. The samples for Total Nitrogen were oven-dried only. Total Nitrogen was determined by the Kjeldahl method. Phosphorus and boron were determined using a spectrophotometer. Potassium was determined by a flame spectrophotometer. Calcium, magnesium, iron, copper, zinc and manganese were determined by atomic absorption spectrometry.

The experimental data were analyzed using Statistica software (StatSoft, 1996), according to the completely randomized design. Analysis of variance (ANOVA) and comparisons of means were calculated using the least significant difference (LSD) test, at the 5\% level of significance.

\section{Results and Discussion}

The use of pulsed electromagnetic field as a presowing treatment was found to enhance durum wheat dry weight, leaf area, photosynthetic rate, transpiration rate, root length, root surface, the absorption of some nutrients and yield.

Total Nitrogen content has been found to increase by the use of magnetic field treatment. The highest values of nitrogen percentage were measured in MF-30 treatment. In both magnetic field treatments, nitrogen percentage was statistically significant higher than control (Table 1).

Magnetic field treatments showed higher values than control in phosphorus, potassium, magnesium, copper (only MF-45), zinc (only MF-30) and boron content. However, values were not statistically higher than control. Magnetic field was found to have a negative effect, statistically not significant, on calcium, iron and 
manganese absorption on durum wheat plants, at the 105 DAS. The two varieties gave statistically significant differences in the content of magnesium, manganese and boron. In a similar research, Esitken and Turan (2004), found that MF has an impact on plant nutrient element uptake from growth media. The increase in the MF strength from control to $0.384 \mathrm{~T}$ increased the concentration of $\mathrm{N}, \mathrm{K}, \mathrm{Ca}, \mathrm{Mg}, \mathrm{Fe}, \mathrm{Mn}$ and $\mathrm{Zn}$ of strawberry plant leaves, but at the $0.384 \mathrm{~T}$ strength concentration of $\mathrm{P}$ and $\mathrm{S}$ decreased compared with control. A considerable increment of $\mathrm{Fe}, \mathrm{Cu}, \mathrm{Mn}, \mathrm{Zn}$, $\mathrm{Mg}, \mathrm{K}$ and $\mathrm{Na}$ contents with reduced level of $\mathrm{Ca}$ was found in PMF treated seedlings of soybean (Radhakrishnan et al., 2012).

Table 1. Pulsed electromagnetic field and variety effect on nutrient absorption of two durum wheat varieties. Seeds have been treated for 0 (control), 30 and 45 minutes with magnetic field

\begin{tabular}{|c|c|c|c|c|}
\hline \multicolumn{5}{|c|}{ Durum Wheat Plant Tissue Analysis } \\
\hline & \multicolumn{2}{|c|}{ Variety } & \multicolumn{2}{|c|}{ Magnetic Field } \\
\hline \multirow{3}{*}{ Total N (\%) } & 'Thraki' & $4.06 \mathrm{~ns}$ & 0 & $3.78 \mathrm{~b}$ \\
\hline & & & 30 & $4.35 \mathrm{a}$ \\
\hline & 'Mexicali' & $4.25 \mathrm{~ns}$ & 45 & $4.33 \mathrm{a}$ \\
\hline \multirow{3}{*}{$\mathrm{P}(\%)$} & 'Thraki' & $0.37 \mathrm{~ns}$ & 0 & $0.35 \mathrm{~ns}$ \\
\hline & 'Mericali' & $037 \mathrm{~ns}$ & 30 & $0.37 \mathrm{~ns}$ \\
\hline & Mexicaul & $0.3 / \mathrm{nS}$ & 45 & $0.38 \mathrm{~ns}$ \\
\hline \multirow{3}{*}{$\mathrm{K}(\%)$} & 'Thraki' & $11.96 \mathrm{~ns}$ & 0 & $10.97 \mathrm{~ns}$ \\
\hline & 'Mericali' & $1126 \mathrm{nc}$ & 30 & $11.83 \mathrm{~ns}$ \\
\hline & Hexican & 11.20115 & 45 & $12.02 \mathrm{~ns}$ \\
\hline \multirow{3}{*}{$\mathrm{Ca}(\%)$} & 'Thraki' & $0.37 \mathrm{~ns}$ & 0 & $0.39 \mathrm{~ns}$ \\
\hline & 'Mexicali' & $036 \mathrm{~ns}$ & 30 & $0.34 \mathrm{~ns}$ \\
\hline & Mexican & $0.50 \mathrm{~ns}$ & 45 & $0.36 \mathrm{~ns}$ \\
\hline \multirow{3}{*}{$\mathrm{Mg}(\%)$} & 'Thraki' & $0.12 \mathrm{a}$ & 0 & $0.11 \mathrm{~ns}$ \\
\hline & 'Mexicali' & $011 \mathrm{~b}$ & 30 & $0.12 \mathrm{~ns}$ \\
\hline & & & 45 & $0.12 \mathrm{~ns}$ \\
\hline \multirow{3}{*}{$\mathrm{Fe}(\mathrm{ppm})$} & 'Thraki' & $136.8 \mathrm{~ns}$ & 0 & $172.2 \mathrm{~ns}$ \\
\hline & 'Mexicali' & $1696 \mathrm{~ns}$ & 30 & $141.8 \mathrm{~ns}$ \\
\hline & & & 45 & $145.5 \mathrm{~ns}$ \\
\hline \multirow{3}{*}{$\mathrm{Cu}(\mathrm{ppm})$} & 'Thraki' & $5.44 \mathrm{~ns}$ & 0 & $6.0 \mathrm{~ns}$ \\
\hline & 'Mexicali' & $6.88 \mathrm{~ns}$ & 30 & $6.0 \mathrm{~ns}$ \\
\hline & & & 45 & $6.5 \mathrm{~ns}$ \\
\hline \multirow{3}{*}{$\mathrm{Zn}(\mathrm{ppm})$} & 'Thraki' & $36.33 \mathrm{~ns}$ & 0 & $38.16 \mathrm{~ns}$ \\
\hline & 'Mexicali' & $40.55 \mathrm{~ns}$ & 30 & $40.16 \mathrm{~ns}$ \\
\hline & viexicain & & 45 & $37.00 \mathrm{~ns}$ \\
\hline \multirow{3}{*}{$\mathrm{Mn}(\mathrm{ppm})$} & 'Thraki' & $37.67 \mathrm{~b}$ & 0 & $43.67 \mathrm{~ns}$ \\
\hline & 'Mexicali' & $48.56 \mathrm{a}$ & 30 & $43.00 \mathrm{~ns}$ \\
\hline & & & 45 & $42.67 \mathrm{~ns}$ \\
\hline \multirow[b]{2}{*}{$\mathrm{B}(\mathrm{ppm})$} & 'Thraki' & $50.94 \mathrm{a}$ & 0 & $44.46 \mathrm{~ns}$ \\
\hline & 'Mexicali' & $46.03 \mathrm{~b}$ & $\begin{array}{l}30 \\
45\end{array}$ & $\begin{array}{l}48.67 \mathrm{~ns} \\
52.33 \mathrm{~ns}\end{array}$ \\
\hline
\end{tabular}

Means followed by the same letter for treatments are not significantly different according to the least significant difference (LSD) test.
Pulsed Electromagnetic Field improved main physiological measurements such photosynthetic rate and transpiration rate (Table 2). Magnetic field treatments had higher values with statistically significant differences compared to control in photosynthetic rate and transpiration rate. In both measurements, the differences between the two varieties were not statistically significant. In spring maize, magneticstimulation was found to optimally improve gaseous exchange parameters (stomatal conductance, transpiration rate and photosynthetic rate), while minimum values for these parameters were found for the control (Afzal et al., 2015).

An interaction of magnetic field and variety has been found at the dry weight measurement (Fig. 1). The highest values were measured in Mex-30 treatment with statistically significant differences, followed by Mex- 45 treatment. The measurements of both magnetic field treatments of 'Thraki' variety gave higher values with statistically significant differences from the control of the same variety and the 'Mexicali' variety. In tomato, magnetic field treatment, in certain times of exposure, improved shoot diameter, number of leaves per plant, fresh and dry weight, number of flowers and yield per plant (Efthimiadou et al., 2015). Martinez et al. (2014), found that variable magnetic field treatment can be a suitable option to increase some germination and early growth variables of broccoli seeds.

The highest value in leaf area was found in 30 and 45 minutes of magnetic field treatment, with statistically significant differences from the control (Fig. 2). In lettuce, all magnetic treatments significantly increased ( $p$ $<0.05$ ) plant height, leaf area per plant, final yield per area and fresh mass per plant, in comparison with the controls (De Souza et al., 2008). In an onion field experiment, pre-sowing magnetic field treatments led to a significant increase in seedling emergence, root length, seedling height, seedling dry weight and leaf area per plant. Also, at the vegetative stage, the leaf and root relative growth rates of plants derived from magnetically treated seeds were greater than those of the control plants (De Souza et al., 2014).

The main root measurements of durum wheat plants were found to be highly affected by electromagnetic field treatment (Fig. 3). The highest root length was recorded in 45 minutes of magnetic field with statistically significant differences from 30 minutes and control treatment. MF-30 gave values statistically significant higher than the control. The two varieties gave values without statistically significant differences. The highest root surface was recorded in 30 minutes of magnetic field

Table 2. Pulsed electromagnetic field and variety effect on physiological measurements of two durum wheat varieties. Seeds have been treated for 0 (control), 30 and 45 minutes with magnetic field

\begin{tabular}{|c|c|c|c|c|}
\hline Parameter & \multicolumn{2}{|c|}{ Variety } & \multicolumn{2}{|c|}{ Magnetic Field } \\
\hline \multirow{3}{*}{ Photosynthetic Rate $\left(\mu \mathrm{mol} \mathrm{CO} \mathrm{CO}^{-2} \mathrm{~s}^{-1}\right)$} & 'Thraki' & $8.38 \mathrm{~ns}$ & 0 & $7.32 \mathrm{~b}$ \\
\hline & 'Mericoli' & $882 n$ & 30 & $8.98 \mathrm{a}$ \\
\hline & Mexicall & $8.83 \mathrm{~ns}$ & 45 & $9.52 \mathrm{a}$ \\
\hline \multirow{3}{*}{ Transpiration Rate $\left(\mathrm{mmol} \mathrm{H}_{2} \mathrm{O} \mathrm{m}^{-2} \mathrm{~s}^{-1}\right)$} & 'Thraki' & $1.18 \mathrm{~ns}$ & 0 & $0.99 \mathrm{~b}$ \\
\hline & 'Mexicali' & $124 \mathrm{~ns}$ & 30 & $1.30 \mathrm{a}$ \\
\hline & Mexicant & $1.24 \mathrm{nS}$ & 45 & $1.34 \mathrm{a}$ \\
\hline
\end{tabular}

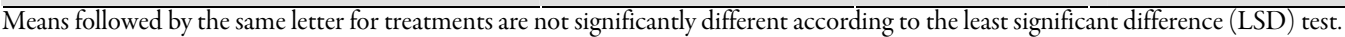


508

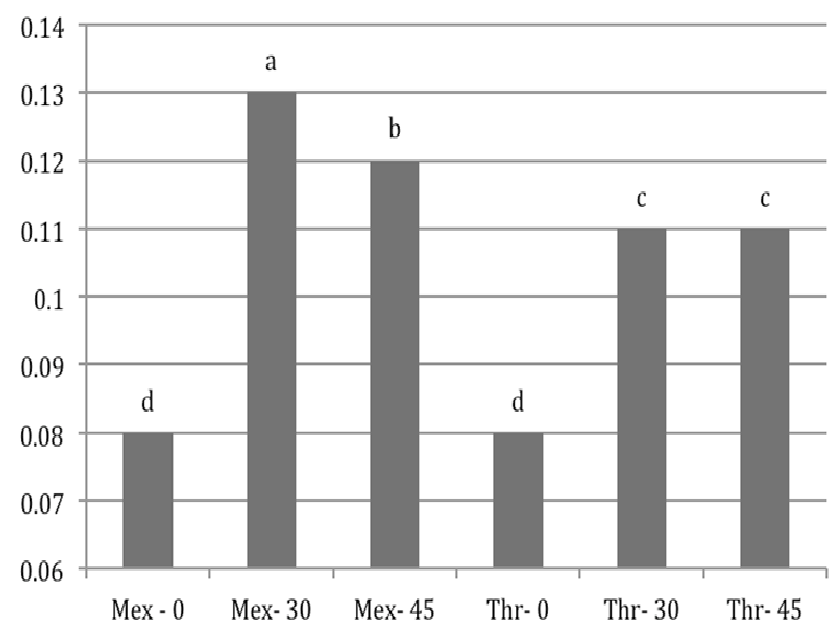

Fig. 1. Interaction of variety and magnetic field treatments on dry weight (g per plant) of two durum wheat varieties. Seeds have been treated for 0 (control), 30 and 45 minutes with magnetic field

Means followed by the same letter for treatments are not significantly different according to the least significant difference (LSD) test.

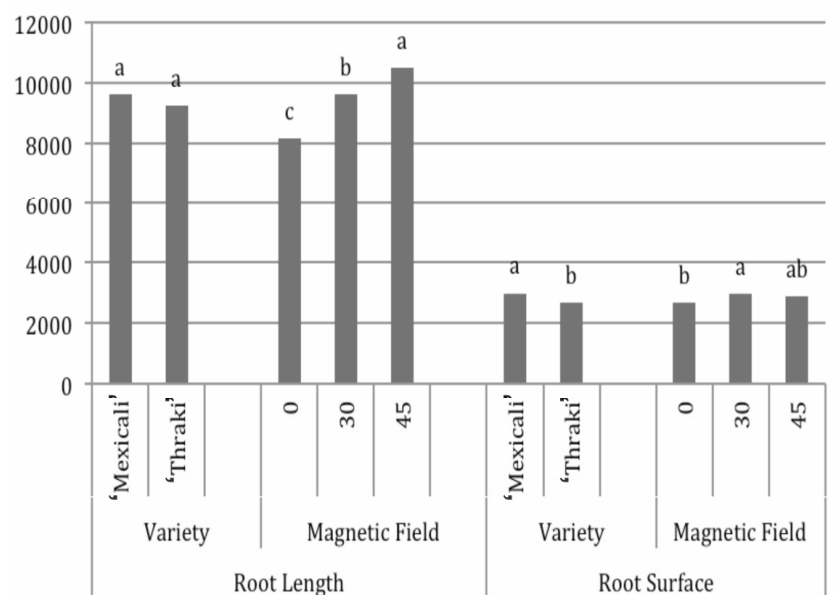

Fig. 3. Pulsed electromagnetic field and variety effect on root length-root surface ( $\mathrm{mm}$ per plant) of two durum wheat varieties. Seeds have been treated for 0 (control), 30 and 45 minutes with magnetic field Means followed by the same letter for treatments are not significantly different according to the least significant difference(LSD) test.

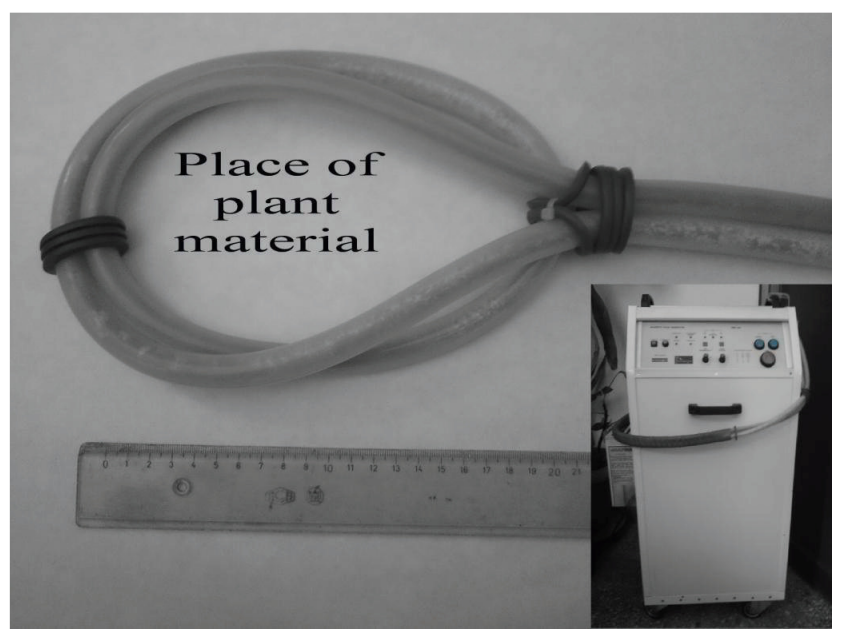

Fig. 5. PAPIMI device and external loop

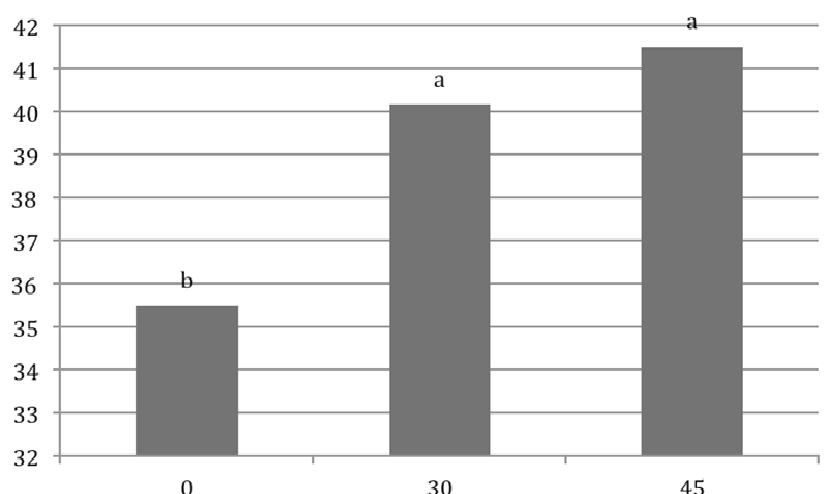

30

45

Fig. 2. Pulsed electromagnetic field impact on leaf area $\left(\mathrm{mm}^{2}\right)$ of two durum wheat varieties. Seeds have been treated for 0 (control), 30 and 45 minutes with magnetic field

Means followed by the same letter for treatments are not significantly different according to the least significant difference(LSD) test.

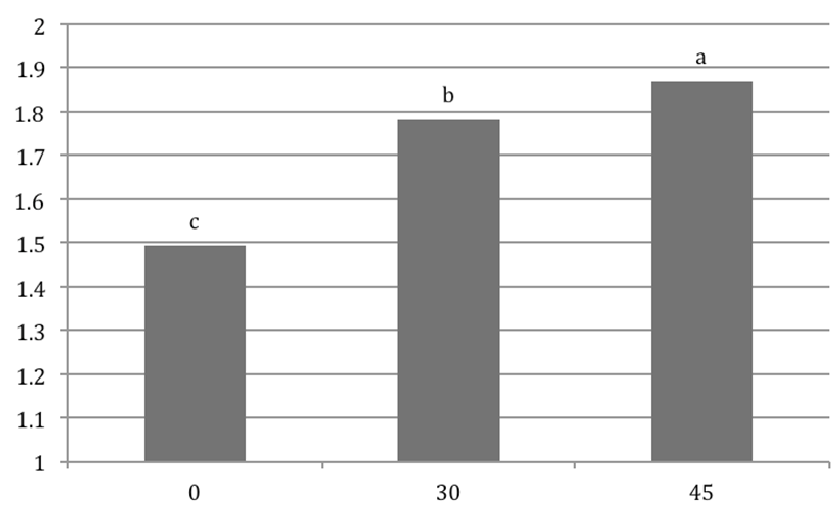

Fig. 4. Pulsed electromagnetic field effect on yield (g per plant) of two durum wheat varieties. Seeds have been treated for 0 (control), 30 and 45 minutes with magnetic field

Means followed by the same letter for treatments are n ot significanty different according to the least significant difference (LSD) test.

treatment with statistically significant differences compared to control. There were no significant differences between 30 and 45 minutes of magnetic field exposure. Similar results have been recorded by Muraji $e t$ al. (1998), who noted that the treatment with alternating magnetic field of 10 and $20 \mathrm{~Hz}$ resulted in $20 \%$ greater root growth of corn seedlings than control plants. Root length, root surface area and root volume also showed significant increases in sunflower seedlings exposed to static magnetic fields of strength from 0-250 mT (Vashisth and Nagarajan, 2010).

Pulsed electromagnetic field was found to have a positive influence on yield of durum wheat. Seeds presowing treated for 45 minutes with magnetic field gave the highest yield with statistically significant differences compared to the 30 minutes treatment and control. Moreover, the treatment of 30 minutes gave higher yield than control with statistically significant differences. Lowintensity magnetic field has been used in strawberry plants and had a positive effect on the yield, in weight and in the number of fruit (Esitken and Turan, 2004). The pretreatment of lettuce seeds with magnetic field also led to an increase in final yield (De Souza et al., 2008). 


\section{Conclusions}

The use of pulsed electromagnetic field as a presowing technique was found to have a positive influence on plant growth, nutrient absorption and yield of durum wheat. This positive effect has been recorded in a wide range of plant measurements, including yield. The current results indicate that this innovative technique can increase the yield of durum wheat, through enhanced absorption of nutrients. Pre-sowing treatment of seeds leads to vigorous plants that are more productive.

\section{Acknowledgements}

This research was funded by the Action "Research \& Technology Development Innovation projects (AgroETAK)", MIS 453350, in the framework of the Operational Program "Human Resources Development". It is co-funded by the European Social Fund and by National Resources through the National Strategic Reference Framework 2007-2013 (NSRF 2007-2013) coordinated by the Hellenic Agricultural Organisation "DEMETER" (Department of Soil Science of Athens / Scientific supervisor: Dr. Victor Kavvadias).

\section{References}

Afzal I, Noor MA, Bakhtavar MA, Ahmad A, Haq Z (2015). Improvement of spring maize (Zea mays) performance through physical and physiological seed enhancements. Seed Science and Technology 43(2):238-239.

Athanasiou A, Karkambounas S, Batistatou A, Lykoudis E, Katsaraki A, Kartsiouni T, ... Evangelou A (2007). The effect of pulsed electromagnetic fields on secondary skin wound healing: an experimental study. Bioelectromagnetics 28(5):362-367.

Bilalis D, Katsenios N, Efthimiadou A, Karkanis A (2012a). Pulsed electromagnetic fields effect in oregano rooting and vegetative propagation: A potential new organic method. Acta Agriculturae Scandinavica Section B-Soil and Plant Science 62:94-99.

Bilalis D, Katsenios N, Efthimiadou A, Karkanis A (2012b). Pulsed electromagnetic field: an organic compatible method to promote plant growth and yield in two corn types. Electromagnetic Biology and Medicine 31(4): 333-343.

Bilalis D, Katsenios N, Efthimiadou A, Karkanis A, Khah EM, Mitsis T (2013). Magnetic field pre-sowing treatment as an organic friendly technique to promote plant growth and chemical elements accumulation in early stages of cotton. Australian Journal of Crop Science 7(1):46-50.

De Souza A, Garci D, Sueiro L, Gilart F, Porras E, Licea L (2006). Pre-sowing magnetic treatments of tomato seeds increase the growth and yield of plants. Bioelectromagnetics 27(4):247257.
De Souza A, Sueiro L, González LM, Licea L, Porras EP, Gilart F (2008). Improvement of the growth and yield of lettuce plants by non-uniform magnetic fields. Electromagnetic Biology and Medicine 27(2):173-184.

De Souza A, García D, Sueiro L, Gilart F (2014). Improvement of the seed germination, growth and yield of onion plants by extremely low frequency non-uniform magnetic fields. Scientia Horticulturae 176:63-69.

Efthimiadou A, Katsenios N, Karkanis A, Papastylianou P, Triantafyllidis V, Travlos I, Bilalis DJ (2014). Effects of presowing pulsed electromagnetic treatment of tomato seed on growth, yield, and lycopene content. The Scientific World Journal.

Esitken A, Turan M (2004). Alternating magnetic field effects on yield and plant nutrient element composition of strawberry (Fragaria $x$ ananassa cv. Camarosa). Acta Agriculturae Scandinavica, Section B, Plant Soil Science 54(3):135-139.

Gupta MK, Anand A, Paul V, Dahuja A, Singh AK (2015). Reactive oxygen species mediated improvement in vigour of static and pulsed magneto-primed cherry tomato seeds. Indian Journal of Plant Physiology 20(3):197-204.

Katsenios N (2013). Investigation of pulsed electromagnetic field influence on plant growth. $\mathrm{PhD}$ Thesis, Agricultural University of Athens, Greece.

Kokko EG, Volkmar KM, Gowen BM, Entz T (1993). Determination of total root surface area in soil core samples by image analysis. Soil Tillage Research 26(1): 33-43.

Martínez FR, Pacheco AD, Pardo GP, Aguilar CH, Ortiz EM (2014). Variable magnetic field effects on seed germination of broccoli (Brassica oleracea L.). Annual Research \& Review in Biology 4(24):3627.

Milgram J, Shahar R, Levin-Harrus T, Kass P (2004). The effect of short high intensity magnetic field pulses on the healing of skin wounds in rat. Bioelectromagnetics 25(4): 271-277.

Muraji M, Asai T, Tatebe W (1998). Primary root growth rate of Zea mays seedlings grown in an alternating magnetic field of different frequencies. Bioelectrochemistry and Bioenergetics 44(2):271-273.

Radhakrishnan R, Ranjitha Kumari BD (2012). Pulsed magnetic field: a contemporary approach offers to enhance plant growth and yield of soybean. Plant Physiology and Biochemistry 51:139-144.

StatSoft Inc (1996). STATISTICA for Windows (Computer program manual). Tusla, OK: StatSoft., Inc, USA.

Vashisth A, Nagarajan S (2010). Effect on germination and early growth characteristics in sunflower (Helianthus annuus) seeds exposed to static magnetic field. Journal of Plant Physiology 167(2):149-156. 